\title{
Leading molecular aspects of plant viruses
}

\section{Introduction}

Plant viruses cause considerable losses in quantity and quality of crops throughout the world. Crops are at risk of virus infection as viruses are difficult to detect and identify. ${ }^{1}$ More than 1000 different plant viruses have been discovered since identification of Tobacco mosaic virus in late $1800 \mathrm{~s}^{2,3}$ Viruses are the second most important plant pathogens after fungi. ${ }^{4}$ Because of the economic importance of these significant plant pathogens, the present review provides primary insight into the plant viral structure and proteins. Further, reports about two important plant virus genera are included.

In general, viruses are minuscule when compared to other plant pathogens such as bacteria and fungi and can be viewed only with electron microscope. ${ }^{5}$ Like other plant pathogens, plant viruses spread and cause major economic losses to various horticultural crops such as barley, corn, potato, rice, tomato, onion and wheat. ${ }^{5-7}$ Plant viruses are supposed to be responsible for economic loss of more than several billions dollars per year worldwide. ${ }^{8}$

Viruses are classified into families and genera based on: 1) the type and size of their nucleic acid, 2) the size and shape of the capsid, and 3) presence or absence of lipid envelope surrounding the nucleocapsid. According to the International Committee on Taxonomy of Viruses (ICTV), plant viruses can be grouped into 73 genera and 49 families. It must be noted that most of the viruses were reported from cultivated plants which in turn represent only a very small fraction of the total number of plant species. ${ }^{9}$ Viruses infecting wild plants have been poorly studied ${ }^{10}$ but since last one and half decade researchers are carrying out various studies to document viruses infecting wild plants. ${ }^{11}$

\section{Viruses structure}

In general, the virus structure is composed of its coat proteins surrounding the viral genome. Assembly of viral particles in a particular shape take place spontaneously. ${ }^{12}$ More than half of known plant viruses have rod-shaped (flexuous or rigid) structure. Although viral particle length usually depends on the genome but in most of the viruses it ranged between $300-500 \mathrm{~nm}$ along with a diameter of $15-20 \mathrm{~nm} \cdot{ }^{13}$ Protein subunits are placed around the circumference of a circle that eventually form a disc. The various are stacked to form a tube-like structure which is having a cavity in middle with a particular shape to harbor the nucleic acid genome. ${ }^{14}$ Isometric particles are the second most common structure amongst plant viruses after rod shape. ${ }^{13}$ The isometric particles are $17-75 \mathrm{~nm}$ in diameter. In plant viruses having only a single coat protein, the basic structure consists of $60 \mathrm{~T}$ subunits, where $\mathrm{T}$ is an integer. While in plant viruses that are having 2 coat proteins, these two sub-units associate to form an icosahedral shaped particle. ${ }^{15}$ The best studied example of the latter case is genera Geminiviridae. They have dual particles i.e., two isometric particles coupled together. ${ }^{16} \mathrm{~A}$ very few plant viruses, in addition to their coat proteins, have a lipid envelope. ${ }^{8}$ The best example of enveloped plant viruses is Tospoviridae family. It is one of the emerging virus family causing enormous economic losses in horticultural crops throughout the world. ${ }^{17}$
Volume 5 Issue 2 - 2017

\author{
Gaurav Raikhy,' Diwaker Tripathi² \\ Department of Biology, University of Washington, USA
}

Correspondence: Diwaker Tripathi, Department of Biology, University of Washington, Seattle, WA, 98105, USA,

Email diwakert@gmail.com

Gaurav Raikhy, Louisiana State University, Health Science Center at Shreveport, Shreveport, LA, 7I I05, USA,

Email graikh@Isuhsc.edu

Received: June 27, 2017| Published: July 27, 2017

\section{Plant viral proteins}

Plant viruses are composed of a coat protein and a single type of nucleic acid, either DNA or RNA. About 3/4th $(\sim 75 \%)$ of plant viruses genomes consist of single stranded RNA (ssRNA). While more than $2 / 3 \mathrm{rd}(\sim 65 \%)$ of plant viruses have positive sense ssRNA, whereas rest of the $10 \%$ have negative sense ssRNA. In plant viruses having -ssRNA genome, they must be converted to +ssRNA before they proceeding to translation. $5 \%$ of total known plant viruses are double stranded RNA and thus, they can be immediately translated as + ssRNA viruses. Approximately $3 \%$ of plant viruses require a reverse transcriptase enzyme to convert between RNA and DNA. About 17\% of known plant viruses are ssDNA (such as Geminiviridae family) and very few are having double stranded DNA (dsDNA) genome (such as Caulimoviridae). When compared to the plant viruses, $1 / 4$ th of animal viruses have dsDNA genome. ${ }^{18}$

\section{Genus potyvirus}

Potyviridae members account for almost a third of the total known plant virus species ${ }^{19}$ and cause more than half the viral crop damage throughout the world, ${ }^{20}$ infecting most economically important horticultural crops. ${ }^{8}$ This is the largest of the genera of plant viruses (about 180 species) and contains some economically important viruses such as Potato virus Y (PVY) and Bean yellow mosaic virus (BYMV). Based on the amino acid sequences of their coat proteins, the Potyiviridae can be divided into six genera. ${ }^{21}$

It is one of the largest genus of plant viruses having one ssRNA component that encodes for one giant polyprotein having size of approximately $350 \mathrm{kDa} .^{22}$ This one large polyprotein is cleaved by 3 different virus-encoded proteases into 10 different mature proteins. The two proteins at the C-terminus of the polyprotein are respectively an RNA-dependent RNA polymerase (RdRp) and the coat protein (CP). Functions of most of the proteins is known, infact, most of the proteins are multifunctional. ${ }^{23}$

\section{Genus tospovirus}

They are enveloped isometric RNA viruses having a tripartite 
genome with small (S), medium (M), and large (L) segments of ssRNA. The genome consists of three negative- or ambisense single-stranded RNAs. ${ }^{24}$ They are transmitted by thrips and are one of the most important plant virus groups infecting a wide range of economically important horticultural crops throughout the world..$^{25,26}$ Tospovirus genus belong to Bunyaviridae family, which is a large group of predominantly animal-infecting viruses. ${ }^{27}$

Tospoviruses have a unique particle morphology, along with genome organization and expression strategies. The virus particles are $80-120 \mathrm{~nm}$ in size and have two viral glycoproteins ${ }^{28}$ Tospoviruses are transmitted by many thrips species. Three thrips species, Frankliniella occidentalis (Western flower thrips), F. fusca (tobacco thrips) and Thrips tabaci (onion thrips) are currently present in the US.

More recently virus research has been focused on understanding the genetics and molecular biology of plant virus genomes, more particularly with focus on elucidation of virus replication and movement. Exploring the viral protein functions to be used by biotechnology companies such as the use of viral derived sequences to provide understanding of virus resistance. Recent technology burst has empowered humans to manipulate plant viruses that may provide unique approach in production of novel proteins in plants.

\section{Acknowledgements}

None.

\section{Conflict of interest}

The author declares no conflict of interest

\section{References}

1. Hadidi A, Czosnek H, Barba M. DNA microarrays and their potential applications for the detection of plant viruses, viroids, and phytoplasmas. J Plant Path. 2004;86(2):97-104.

2. King AMQ, Adams MJ, Eric BC, et al. Virus Taxonomy: Ninth Report of the International Committee on Taxonomy of Viruses. USA: Elsevier; 2011. 1339 p.

3. Scholthof KBG. Tobacco mosaic virus. The Plant Health Instructor. 2000 .

4. Vidaver AK, Lambrecht PA. Bacteria as plant pathogens. The Plant Health Instructor. 2004

5. Ellis SD, Boehm MJ, Qu F. Agriculture and Natural Resources: Vira Diseases of Plants (PP401.05). Plant Pathology. 5th ed. USA: Elsevier; 2008. $922 \mathrm{p}$

6. Strange RN, Scott PR. Plant disease: a threat to global food security. Annu Rev Phytopathol. 2005;43:83-116.

7. Hull R. Matthew's Plant Virology. 4th ed. NY: Academic Press; 2002. $1001 \mathrm{p}$.

8. Breitbart M, Rohwer F. Here a virus, there a virus, everywhere the same virus? Trends Microbiol. 2005;13(6):278-284.

9. Cooper I, Jones RA. Wild plants and viruses: Underinvestigated ecosystems. Adv Virus Res. 2006;67:1-47.
10. Roossinck MJ. The good viruses: viral mutualistic symbioses. Nature Rev Microbiol. 2011;9(2):99-108.

11. Lodish H, Berk A, Zipursky SL. Molecular Cell Biology. 4th ed. USA: WH Freeman, Section $6.3 ; 2000$

12. Buttner C, von Bargen S, Bandte M, Muhlbach HP () Forest Diseases Caused by Viruses. In: Gonthier P, Nicolotti G, editors. Infectious Forest Diseases. UK: CAB International; 2013. 613 p

13. Gray SM, Banerjee N. Mechanisms of Arthropod Transmission of Plant and Animal Viruses. Microbiol Mol Biol Rev. 1999;63(1):128-148.

14. Prasad BV, Schmid MF. Principles of virus structural organization. $A d v$ Exp Med Biol. 2012;726:17-47.

15. Krupovic M, Ravantti JJ, Bamford DH. Geminiviruses: a tale of a plasmid becoming a virus. BMC Evol Biol. 2009;9:112-122.

16. Elliott RM. Emerging viruses: The Bunyaviridae. Mol Med. 1997;3(9):572-577.

17. TechVert. Evidence of First Virus That Moves from Plants to Humans. TechVert. 2010

18. Fauquet CM, Mayo MA, Maniloff J, et al. Virus taxonomy: eighth report of the International Committee on Taxonomy of Viruses. United Kingdom: Elsevier/Academic Press; 2005.

19. López-Moya JJ, García JA. Potyviruses (Potyviridae). In: Mahy BWJ, Van Regenmortel MHV, editors. Encyclopedia of Virology. 3rd ed. United Kingdom: Elsevier/Academic Press; 2008.

20. Adams MJ, Antoniw JF, Fauquet CM. Molecular criteria for genus and species discrimination within the family Potyviridae. Arch Virol. $2005 ; 150: 459-479$.

21. Lee KC, Wong SM. Variability of P1 protein of zucchini yellow mosaic virus for strain differentiation and phylogenetic analysis with other potyviruses. DNA Seq. 1998;9(5-6):275-293.

22. Chung BY, Miller WA, Atkins JF, et al. An overlapping essential gene in the Potyviridae. Proc Natl Acad Sci USA. 2008;105(15):5897-5902.

23. Qiu WP, Geske SM, Hickey CM, et al. Tomato Spotted Wilt Tospovirus Genome Reassortment and Genome Segment-Specific Adaptation. Virology. 1998;244(1):186-194.

24. Pappu HR, Jones RA, Jain RK. Global status of tospovirus epidemics in diverse cropping systems: Successes achieved and challenges ahead. Virus Res. 2009;141(2):219-236.

25. Varma A, Jain RK, Bhat AI. Virus resistant transgenic plants for environmentally safe management of viral diseases. Indian J Biotechnol. $2002 ; 1: 73-86$

26. Alatoom A, Payne D. An overview of Arboviruses and Bunyaviruses Lab Medicine. 2009;40(4):237-240.

27. Turnia M, Kormelink R, Resende RO. Resistance to Tospoviruses in vegetable crops: epidemiological and molecular aspects. Annu Rev Phytopathol. 2016;54:1-25.

28. Riley DG, Joseph SV, Srinivasan R, et al. Thrips vectors of Tospoviruses J Integ Pest Mngmt. 2011;1(2):2011. 